Original Article

\title{
Characterization of wheat-Thinopyrum bessarabicum genetic stock for stripe rust and Karnal bunt resistance
}

\author{
Caracterização do estoque genético de trigo-Thinopyrum bessarabicum para resistência \\ de ferrugem e Karnal bunt
}

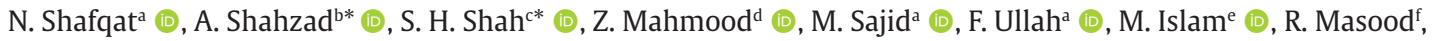 \\ N. Jabeen ${ }^{\mathrm{a}}$ (D) and K. Zubaire (D) \\ aHazara University, Department of Agriculture, Mansehra, Pakistan \\ ${ }^{b}$ National Institute for Genomics and Advanced Biotechnology - NIGAB, National Agricultural Research Centre - NARC, Islamabad, Pakistan \\ ${ }^{c}$ Allama Iqbal Open University, Faculty of Sciences, Department of Agricultural Sciences, Islamabad, Pakistan \\ dNational Agricultural Research Centre - NARC, Wheat Program, Islamabad, Pakistan \\ eHazara University Mansehra, Department of Genetics, Mansehra, Pakistan \\ fHazara University Mansehra, Department of Botany, Mansehra, Pakistan
}

\begin{abstract}
Utilization of modern breeding techniques for developing high yielding and uniform plant types ultimately narrowing the genetic makeup of most crops. Narrowed genetic makeup of these crops has made them vulnerable towards disease and insect epidemics. For sustainable crop production, genetic variability of these crops must be broadened against various biotic and abiotic stresses. One of the ways to widen genetic configuration of these crops is to identify novel additional sources of durable resistance. In this regard crops wild relatives are providing valuable sources of allelic diversity towards various biotic, abiotic stress tolerance and quality components. For incorporating novel variability from wild relative's wide hybridization technique has become a promising breeding method. For this purpose, wheat-Th. bessarabicum amphiploid, addition and translocation lines have been screened in field and screen house conditions to get novel sources of yellow rust and Karnal bunt resistant. Stripe rust screening under field conditions has revealed addition lines $4 \mathrm{JJ}$ and $6 \mathrm{JJ}$ as resistant to moderately resistant while addition lines 3JJ, 5JJ, 7JJ and translocation lines $\mathrm{Tr}-3$, Tr-6 as moderately resistant wheat-Thinopyrum-bessarabicum genetic stock. Karnal bunt screening depicted addition lines 5JJ and 4JJ as highly resistant genetic stock. These genetic stocks may be used to introgression novel stripe rust and Karnal bunt resistance from the tertiary gene pool into susceptible wheat backgrounds.
\end{abstract}

Keywords: wheat (Thinopyrum bessarabicum) addition and translocation lines, yellow rust, Karnal bunt, biotic stress resistance.

\begin{abstract}
Resumo
A utilização de técnicas modernas de melhoramento para o desenvolvimento de tipos de plantas uniformes e de alto rendimento, em última análise, estreitando a composição genética da maioria das culturas. A composição genética restrita dessas plantações tornou-as vulneráveis a doenças e epidemias de insetos. Para uma produção agrícola sustentável, a variabilidade genética dessas culturas deve ser ampliada contra vários estresses bióticos e abióticos. Uma das maneiras de ampliar a configuração genética dessas culturas é identificar novas fontes adicionais de resistência durável. A esse respeito, os parentes selvagens das culturas estão fornecendo fontes valiosas de diversidade alélica para vários componentes de qualidade e tolerância ao estresse abiótico e biótico. Para incorporar a nova variabilidade da ampla técnica de hibridização de parente selvagem tornou-se um método de reprodução promissor. Para esse efeito, trigo-Th. As linhas anfiploides, de adição e translocação de bessarabicum foram selecionadas em condições de campo e de casa de tela para obter novas fontes de ferrugem amarela e resistência ao bunt de Karnal. A triagem de ferrugem em faixas em condições de campo revelou as linhas de adição 4JJ e 6JJ como resistentes a moderadamente resistentes, enquanto as linhas de adição 3JJ, 5JJ, 7JJ e as linhas de translocação Tr-3, Tr-6 como estoque genético de trigo-Thinopyrum bessarabicum moderadamente resistente. A triagem Karnal bunt descreveu as linhas de adição 5JJ e 4JJ como estoque genético altamente resistente. Esses estoques genéticos podem ser usados para introgressão da nova ferrugem e resistência ao bunt de Karnal do pool genético terciário em origens de trigo suscetíveis.
\end{abstract}

Palavras-chave: linha de adição e translocação de trigo (Thinopyrum bessarabicum), ferrugem amarela, Bunt Karnal, resistência ao estresse biótico.

*e-mail: armghan.shahzad@parc.gov.pk; sabir.hussain@aiou.edu.pk

Received: December 10, 2020- Accepted: March 24, 2021

This is an Open Access article distributed under the terms of the Creative Commons Attribution License, which permits unrestricted use, distribution, and reproduction in any medium, provided the original work is properly cited. 


\section{Introduction}

World's diet constitutes about 93 percent of the plants. Among these plants, cereals contribute two-thirds of all food. Wheat, maize and rice constitute about 80 percent of total global cereal production (Getachew and Biruk, 2018). Wheat (Triticum aestivum $\mathrm{L}$.) is the world's leading cereal grain used as staple food by more than one third of the world's population (FAO, 2018). It is a leading source of calories as well as protein consumption for both humans and livestock (Narang et al., 2020). Modern day agriculture is facing severe challenges from biotic and abiotic stresses, threating its food security and sustainable development (Jinya et al., 2020). Among various kinds of biotic stresses, fungi are the most devastating one causing the majority of plant diseases (Robert-Seilaniantz et al., 2011). Wheat crop is hosted by variety of fungal pathogens which causes infection at different developmental stages; among them the important ones are stripe rust and karnal bunt. (Bishnoi et al., 2020). Most important wheat foliar disease yellow rust (stripe rust) is caused by a fungus known as Puccinia striiformis f. sp. tritici. Almost all the continents except Antarctica host this disease (Ali et al., 2017). Wheat grain loss of about 30 to $100 \%$ due to this fungus imposing global threat to wheat production (Chen, 2005). Various reports have revealed that this disease had the ability to destroy the entire wheat crops under favorable conditions (Mengesha, 2020). In Pakistan, losses due to this disease are not estimated (Shakoor et al., 2015), but at global level yield loss of at least 5.5 million tons per year is caused by yellow rust disease (Marcelo et al., 2020). Puccinia striiformis f. sp. destroys the plants respiratory system by causing necrosis, stunting plant growth and by reducing grain yield (Line, 2002; Chen, 2005). Defending measures against the destruction of this pathogen are of primary concern for world food security (Chakravarty, 2011). Diverse disease control strategies like use of chemicals and agronomic practices are proven profitable to lessen the losses (Foster et al., 2017), but it has been reported that recurrent use of the same chemical fungicide for several years under extensive wheat production area might favor the development of resistant pathogens ultimately necessitating the use of alternate fungicide (Getachew and Biruk, 2018). So, in this situation host genetic resistance is the most practicable method to control stripe rust alternatively. Crops genetic resistance exploitation is economical, and bears no health and environmental hazards and proving resistant for a longer period of time ensuring crop sustainability (Hovmøller et al., 2017; Farrokhi et al., 2011). Stripe rust resistance of two types, all-stage resistance (also called race specific) and adult-plant resistance (also called race nonspecific) have been identified. Among these two types, adult plant resistance (Apr) has been found to be effective against all races conferring durable resistance. (Chen, 2013). On the contrary, race specific resistance becomes ineffective within three to five years (Line and Qayoum, 1992). Strategy of pyramiding these major (race specific) and minor (race non-specific) genes (Singh et al., 2004) could result in sustainable resistance. Tilletia Indica Mitra causing karnal bunt disease of wheat reported first time from Karnal,
Haryana, India in 1931 (Mitra 1931). Bonde et al. (1997) and Rush et al. (2005) have also reported the prevalence of this disease in other countries. Karnal Bunt infection does not cover the entire wheat ear, rather it restricts its infection to a few kernels within a spike and to a part of the grain and rarely the whole grain, thereby, the disease has also been given the name partial bunt (Pandey et al., 2019). The fungus infests the ovaries in the emerging wheat heads resulting in partially or completely filled powdery masses of teliospores emitting a foul smell of trimethylamine (Shakoor et al., 2015). Wheat grains infected with KB are of low quality as they port an unacceptable odor, color, and taste and at as low as $1 \%$ infection the grains/flour become unpalatable (Kashyap et al., 2018). Most devastating effect of Karnal bunt (KB) is to quarantine regulations that may restrict the free global trade of wheat besides the loss of grain yield and quality as well (Bishnoi et al., 2020; Sukhwinder et al., 2007). Cultural practices and chemical treatments have been futile due to soil-borne and an airborne sporidial stage (Carris et al., 2006; Garrett and Bowden, 2002, Kumar et al., 2014). The morphological barriers as well as the physiological traits manifests the genetic resistance against KB fungus in wheat and Durum. For example, the higher degree of resistance expressed by triticale and durum wheat in comparison to bread wheat is attributed to the morphological defense barriers like pubescence rather than it being physiological (Warham, 1988). The morphological traits like leaf sheath, flag leaf base, glumes and rachis with higher number of stomata and glumes and rachis with low hair count and compact arrangement of spikelets are relevant to the resistant lines (Bishnoi et al., 2020). The Gogoi et al. (2002) elaborated that relatively more resistant durum wheat and triticale have lower glume opening and low ear emergence period. Thus, the best approach to protect the crop from yellow rust and Karnal bunt pathogens is to breed for genetic resistance. (McIntosh et al., 2018). Due to limited genetic diversity within cultivated crops (Reif et al., 2005), cytogeneticists, breeders and farmers are sorting out additional and novel sources of resistance from primary, secondary, and tertiary gene pools of wheat (Feuillet et al., 2008, Milus et al.., 2015). Wheat wild relatives from tertiary gene pool are providing valuable sources of genetic diversity having a variety of R genes for rust and Karnal bunt resistance that could enable more sustainable disease control (Kerber and Dyck, 1990; Narang et al., 2020). Genes from over 52 allien species including T. umbellulatum, T. comosum, Thinopyrum intermedium, Th. elongatum, Th. ponticum and Secale cereale have been introgressed (McIntosh et al., 1995) into wheat to exploit natural variation of alien species for wheat improvement (Wulff and Moscou, 2014).

In this regard, characterization of various wheat-allien genetic stocks for identification of such novel resistances is paramount. Keeping in view the importance of Yellow rust and Karnal bunt diseases, Present study was carried out to screen wheat-Th. bessarabicum genetic stocks possessing resistance against stripe rust and Karnal bunt to enhance cultivar improvement by using these wheat-allien genetic stocks in breeding programs in Pakistan. 


\section{Materials and Methods}

\subsection{Field evaluation for stripe rust resistance}

Wheat-Th. bessarabicum genetic stocks along with Chinese Spring wheat variety, and standard check variety Morocco (Table 1) were screened for adult plant resistance in field conditions of NARC Islamabad during wheat growing cycles (2012-2015). The material was raised in Randomize Complete Block design (RCBD) with three replications. Each plot consisted of one row of $2.5 \mathrm{~m}$ length spaced at $30 \mathrm{~cm}$ between rows and $15 \mathrm{~cm}$ between plants. Every fifth row was seeded with Morocco check cultivar. Other recommended cultural practices for wheat production were followed during the growing seasons. All the genetic stock was inoculated thrice by Uredio-spore suspension to create stripe rust epidemic after 6 weeks of planting. The data were analyzed by using modified Cobb scale (Mengesha, 2020).

\subsection{Disease scoring for adult plant resistance}

Data was taken at flag leaf stage for disease severity and infection after every 10-days interval. The data was recorded by using modified Cobb scale (Mengesha, 2020) as percent (\%) of the rust infection on the plants surface. Field response referring to the type of infection was recorded

Table 1. Pdigree of wheat-Th. bessarabicum genetic stocks.

\begin{tabular}{|c|c|}
\hline $\begin{array}{l}\text { Genetic } \\
\text { Stock }\end{array}$ & Pedigree \\
\hline $\operatorname{Tr}-1$ & 6BS.6BL-6J (CS/Th.bess//CSph/3/4*Prinia \\
\hline $\operatorname{Tr}-2$ & 1DS.1JS \\
\hline $\operatorname{Tr}-3$ & 3JS.3BL, (CS/Th.bess//CSph/3/3*Prinia \\
\hline $\operatorname{Tr}-4$ & 1AS.1AL-1JL \\
\hline $\operatorname{Tr}-5$ & 7DS.7DL-4J, (CS/Th.bess//CSph/3/4*Prinia \\
\hline $\operatorname{Tr}-6$ & 6JS.7DL, (CS/Th.bess//CSph/3/4*Prinia \\
\hline $\operatorname{Tr}-7$ & 5JS.5DS.5DL \\
\hline Amphiploid & CS/Thinopyrum bessarabicum \\
\hline $1 \mathrm{JJ}$ & $\mathrm{CS}+1 \mathrm{JJ}(2 \mathrm{n}=6 \mathrm{x}=42+2=\mathrm{AABBDD}+1 \mathrm{JJ})$ \\
\hline $2 \mathrm{JJ}$ & $\mathrm{CS}+2 \mathrm{JJ}(2 \mathrm{n}=6 \mathrm{x}=42+2=\mathrm{AABBDD}+2 \mathrm{JJ})$ \\
\hline $3 \mathrm{JJ}$ & $\mathrm{CS}+3 \mathrm{JJ}(2 \mathrm{n}=6 \mathrm{x}=42+2=\mathrm{AABBDD}+3 \mathrm{JJ})$ \\
\hline $4 \mathrm{JJ}$ & $\mathrm{CS}+4 \mathrm{JJ}(2 \mathrm{n}=6 \mathrm{x}=42+2=\mathrm{AABBDD}+4 \mathrm{JJ})$ \\
\hline $5 \mathrm{JJ}$ & $\mathrm{CS}+5 \mathrm{JJ}(2 \mathrm{n}=6 \mathrm{x}=42+2=\mathrm{AABBDD}+5 \mathrm{JJ})$ \\
\hline $6 \mathrm{JJ}$ & $\mathrm{CS}+6 \mathrm{JJ}(2 \mathrm{n}=6 \mathrm{x}=42+2=\mathrm{AABBDD}+6 \mathrm{JJ})$ \\
\hline $7 \mathrm{JJ}$ & $\mathrm{CS}+7 \mathrm{JJ}(2 \mathrm{n}=6 \mathrm{x}=42+2=\mathrm{AABBDD}+7 \mathrm{JJ})$ \\
\hline $3 \mathrm{JJ} 42$ & $\mathrm{CS}+\operatorname{Tr} 3 \mathrm{~J}(2 \mathrm{n}=6 \mathrm{x}=42=\mathrm{AABBDD}+\operatorname{Tr} 3 \mathrm{~J})$ \\
\hline 3JJ44 & $\mathrm{CS}+\operatorname{Tr} 3 \mathrm{JJ}(2 \mathrm{n}=6 \mathrm{x}=42+2=\mathrm{AABBDD}+\operatorname{Tr} 3 \mathrm{JJ})$ \\
\hline $\begin{array}{l}\text { CS/bess// } \\
\text { Pav }\end{array}$ & $\begin{array}{l}\text { CS } / \text { Th. bess } / / \text { Pavon } \\
(7 \mathrm{x}=49=42+7=\text { AABBDDJ })\end{array}$ \\
\hline $\begin{array}{l}\text { CS/bess// } \\
\text { Gen }\end{array}$ & $\begin{array}{l}\text { CS } / \text { Th. bess } / / \text { Genaro } \\
(7 \mathrm{x}=49=42+7=\text { AABBDDJ })\end{array}$ \\
\hline $\begin{array}{l}\text { CS, Genaro } \\
81, \text { Morroco }\end{array}$ & Wheat cultivars \\
\hline
\end{tabular}

according to the Table 2 . The data was recorded for disease severity first time when the susceptible check (Morocco) had reached up to $100 \%$ disease infection (Table 2 ).

\subsection{Karnal bunt}

\subsubsection{Inoculation technique and disease scoring}

For Karnal bunt screening, $1 \mathrm{ml} \mathrm{tiller}^{-1}$ sporodial suspension taken from Crop disease research institute (CDRI) of NARC Islamabad was injected by using a hypodermal syringe at booting stage (Stages 48-49) (Zadoks et al., 1974) for two consecutive wheat growing cycles in NARC fields, i.e., 2013-2015. Tagging of injected tillers was done. Susceptibility category was evaluated for all genetic stocks inoculated on the basis of CI Table 3, following the susceptibility category given by Aujla et al. (1989).

\section{Results}

\subsection{Stripe Rust and Karnal bunt}

Wheat-Thinopyrum bessarabicum addition and translocation lines along with Chines Spring variety, Chines Spring wheat-Thinopyrum bessarabicum amphiploid and check cultivar Morocco were screened for stripe rust resistance. Yellow rust disease surveillance was done by using modified Cobb scale (Mengesha, 2020). Data for rust resistance evaluation is represented in Table 4. Average Coefficient of infection (ACI) for these genetic stocks is calculated from $\mathrm{CI}$ (Coefficient of infection) values of each genetic stock shown in the Table 4 . WheatThinopyrum bessarabicum addition line 4JJ (2.0) and 6JJ (2.33) distinguished as resistant material toward stripe rust fungal pathogen (Table 4). Addition line 3JJ (9.3), 5JJ (13.3), 7JJ (6.67), Tr-3 (10.0) and Tr-6 (11) were ranked as moderately resistant (Table 4$)$. Translocation lines Tr-4 (16.0), Tr-5 (26.67) comes under moderately susceptible category while addition line $1 \mathrm{JJ}$ (34.0), translocation lines Tr-1 (38.0), Tr-2 (32.0), Tr-7 (42.0), Tr-8 and Tr-9 (34.0) behaved as susceptible and wheat cultivar used in developing these addition and translocation lines CS and amphiploid were late.

\subsection{Karnal bunt}

Percent incidence caused by Tilletia indica showed variety of susceptibility categories in all wheat-Th. bessarabicum genetic stocks (Table 5). Wheat-Thinopyrum bessarabicum addition line 4JJ, 5JJ and amphiploid delineated highly resistant attitude, addition line 2JJ, 3JJ, 7JJ, translocation line Tr-1. Tr-3, Tr-5, Tr-7, Tr-42, Tr-44, and two BC1s self-fertile lines were ranked as resistant (Table 6). 6JJ addition line comes under moderately susceptible category while addition line $1 \mathrm{JJ}$, translocation lines $\operatorname{Tr}-2, \operatorname{Tr}-4, \operatorname{Tr}-6$, and wheat cultivars used in developing these addition and translocation lines Genaro-81 showed response as susceptible (Table 6). 
Table 2. Rust reaction, infection type for field response and response value.

\begin{tabular}{|c|c|c|c|}
\hline Reaction & $\begin{array}{l}\text { Infection } \\
\text { type }\end{array}$ & Field response & Response value \\
\hline No disease & 0 & No visible infection & 0 \\
\hline Resistant & $\mathrm{R}$ & Necrotic areas with or without minute uredia & 0.2 \\
\hline Moderately resistant & MR & Small uredia present surrounded by necrotic area & 0.4 \\
\hline Moderately resistant & MRMS & $\begin{array}{l}\text { Small uredia present surrounded by necrotic areas } \\
\text { as well as medium }\end{array}$ & 0.6 \\
\hline moderately susceptible & MS & $\begin{array}{l}\text { uredia with no necrosis but possible some distinct } \\
\text { chlorosis }\end{array}$ & \\
\hline Moderately susceptible & & $\begin{array}{l}\text { Medium uredia with no necrosis but possible some } \\
\text { distinct chlorosis }\end{array}$ & 0.8 \\
\hline $\begin{array}{l}\text { Moderately susceptible- } \\
\text { susceptible }\end{array}$ & MSS & $\begin{array}{l}\text { Medium uredia with no necrosis but possible some } \\
\text { distinct chlorosis as well as large uredia with little } \\
\text { or chlorosis present }\end{array}$ & 0.9 \\
\hline Susceptible & $S$ & Large uredia and little or no chlorosis present & 1 \\
\hline
\end{tabular}

(Mengesha, 2020).

Table 3. Standardization of vulnerability category based on $\mathrm{Cl}$ value.

\begin{tabular}{cc}
\hline $\begin{array}{c}\text { Co-efficient of } \\
\text { Infection }(\mathbf{C I})\end{array}$ & Susceptibility Category \\
\hline 0 & Highly resistant (HR) \\
$0.1-5.0$ & Resistant (R) \\
$5.1-10.0$ & Moderately Susceptible (MS) \\
$10.1-20.0$ & Susceptible (S) \\
20.0 and above & Highly Susceptible (HS) \\
\hline
\end{tabular}

(Aujla et al., 1989).

\section{Discussion}

Wheat is the largest cereals crop of the world. Despite its importance as cereal crop, its yield and productions are prone to various biotic and abiotic factors among which wheat rust diseases are the most important. One of the most important objectives of wheat breeding programs in all wheat growing regions of the world is to develop durable tolerance against yellow rust in wheat cultivars (Akfirat et al., 2010). Durable resistance can be obtained by pyramiding various ASR and APR genes into one variety (Klarquist et al., 2016). Due to swift breakdown of commercially deployed resistance genes, characterization of diverse and novel sources of resistance is constantly needed to replace the defeated genes. Wheat wild relatives are a potential source of novel rust resistance genes for developing new and diverse resistant germplasm (Kerber and Dyck, 1990). In present study, wheat-Th. bessarabicum addition line 4JJ and 6JJ exhibited resistance attitude towards yellow rust (Table 4 ). As these lines were not immune to yellow rust indicating the presence of minor genes which are desirable for durable resistance. Two novel QTLs for adult plant resistance have already been identified on group 4A and 6B chromosomes of wheat (Klarquist et al., 2016). Other addition lines 3JJ, 5JJ,
7JJ, and translocation lines Tr-3 (3JS.3BL), Tr-6 (6JS.7DL) were ranked as moderately resistant. Several QTLs for stripe rust resistance have been shown in group 3, 5 and 7 of wheat (Rosewarne, et al., 2013). It can be concluded that chromosome 3J, 5J, 4J, 6J and 7J of Th. bessarabicum may possess some of the adult plant resistance (APR) genes loci which have provided adult plant resistance against stripe rust in $3 \mathrm{JJ}$, 5JJ, 4JJ, $6 \mathrm{JJ}$ and $7 \mathrm{JJ}$ additions and translocation lines in CS background. Data for CS and amphiploid could not be taken due to late maturity of these materials. Karnal bunt or partial bunt, caused by T. indica (syn. Neovossia indica [Mitra] Mundkur) also occurs endemically in (Punjab) Pakistan (Sajjad et al., 2018). For screening the germplasm, boot inoculation technique is one of the useful methodologies that allow the maximum ratio of successful infection (Beniwal et al., 2001). There is scarceness of resistance in the commercial cultivars against Karnal bunt in the country (Raza et al., 2019) and across the border (Bishnoi et al., 2020). Due to lack of resistance in commercial cultivars (Shakoor et al., 2015) wheat Th. bessarabicum genetic stock has been evaluated by boot inoculation technique. Results showed that amphiploid and addition lines $4 \mathrm{JJ}$, 5JJ are immune to the KB while addition line 2JJ, 3JJ, 7JJ, translocation line Tr-1, Tr-3, Tr-5, Tr-7, Tr-42, Tr-44, and two BC1s self-fertile lines were ranked as resistant (Table 6 ). $\mathrm{KB}$ resistance in wheat is polygenic (Brar et al., 2018; Gupta et al., 2019). This polygenic resistant attitude was partly based on the fact that six wheat chromosomes (1D, 2A, 3B, 3D, 5D, 7A) were attributed to influence the reaction against the pathogen (Gill et al., 1993; Singh et al., 1994). . In 2019, Gupta et al. also reported novel QTLs on chromosomes 1DL, 2DL, 4AL, 5AS, 6BL, 6BS, 7BS, and 7DL. Nine other QTLs were also detected on chromosomes 3B, 4A, 4B, 5A, 5B, and 7A (Brar et al., 2018; Singh et al., 2007). It is probable that there are numeral genes that affect resistance against $\mathrm{KB}$, because diverse mechanisms could operate for shielding the plant against the pathogen and each of them may be controlled by different genes (kumar et al., 2019; Gurjar et al., 2019; 
Table 4. Response of wheat-Thinopyrum bessarabicum genetic stocks to yellow rust infections during 2012 -2015.

\begin{tabular}{|c|c|c|c|c|c|c|c|c|}
\hline \multirow{2}{*}{ Serial No } & \multirow{2}{*}{ Genotypes } & \multirow{2}{*}{ 2012-13 } & \multirow{2}{*}{ 2013-14 } & \multirow{2}{*}{ 2014-15 } & \multirow{2}{*}{$\begin{array}{c}\text { CI } \\
2012-13\end{array}$} & \multirow{2}{*}{$\begin{array}{c}\text { CI } \\
2013-14\end{array}$} & \multirow{2}{*}{$\begin{array}{c}\text { CI } \\
2014-15\end{array}$} & \multirow{2}{*}{ ACI } \\
\hline & & & & & & & & \\
\hline 1 & $1 \mathrm{JJ}$ & 50MRMS & 60MRMS & 60MRMS & 30 & 36 & 36 & 34 \\
\hline 2 & 2JJ & 30MRMS & $20 \mathrm{MR}$ & 20MRMS & 18 & 8 & 12 & 12.23 \\
\hline 3 & 3JJ & $20 \mathrm{MR}$ & 20MRMS & $20 \mathrm{MR}$ & 8 & 12 & 8 & 9.3 \\
\hline 4 & $4 \mathrm{JJ}$ & 5RMR & 10RMR & 5RMR & 1.5 & 3 & 1.5 & 2 \\
\hline 5 & $5 \mathrm{JJ}$ & $25 \mathrm{MR}$ & $30 \mathrm{MR}$ & 30MRMS & 10 & 12 & 18 & 13.3 \\
\hline 6 & $6 \mathrm{JJ}$ & 5RMR & 10MR & 5RMR & 1.5 & 4 & 1.5 & 2.33 \\
\hline 7 & 7JJ & $10 \mathrm{MR}$ & $20 \mathrm{MR}$ & 20MR & 4 & 8 & 8 & 6.67 \\
\hline 8 & $\operatorname{Tr}-1$ & 60MRMS & 70MRMS & 60MRMS & 36 & 42 & 36 & 38 \\
\hline 9 & $\operatorname{Tr}-2$ & 50MRMS & 60MRMS & 50MRMS & 30 & 36 & 30 & 32 \\
\hline 10 & $\operatorname{Tr}-3$ & 20RMR & $30 \mathrm{MR}$ & $30 \mathrm{MR}$ & 6 & 12 & 12 & 10 \\
\hline 11 & $\operatorname{Tr}-4$ & 40RMR & 50MR & 40MR & 12 & 20 & 16 & 16 \\
\hline 12 & $\operatorname{Tr}-5$ & 40MRMS & 50MRMS & 40MRMS & 26 & 30 & 24 & 26.67 \\
\hline 13 & $\operatorname{Tr}-6$ & 30RMR & $30 \mathrm{MR}$ & 20MRMS & 9 & 12 & 12 & 11 \\
\hline 14 & $\operatorname{Tr}-7$ & 60MRMS & 80MRMS & 70MRMS & 36 & 48 & 42 & 42 \\
\hline 15 & CS & Late & $20 \mathrm{MR}$ & TMR & 0 & 8 & 0 & 8 \\
\hline 16 & Amphiploid & Late & 0 & 0 & 0 & 0 & 0 & 0 \\
\hline 19 & Morocco & $100 \mathrm{~S}$ & $100 \mathrm{~S}$ & $100 \mathrm{~S}$ & & & & \\
\hline
\end{tabular}

Table 5. Susceptibility category of each wheat-Thinopyrum bessarabicum genetic stock, based on coefficient of infection when inoculated with mixture of isolates.

\begin{tabular}{|c|c|c|c|c|c|c|c|c|c|c|c|}
\hline Genotypes & $\begin{array}{c}\text { Total } \\
\text { Grains }\end{array}$ & $\begin{array}{c}\text { Infested } \\
\text { Grains }\end{array}$ & $\begin{array}{c}\% \\
\text { infection }\end{array}$ & 0 & 1 & 2 & 3 & 4 & 5 & $\begin{array}{l}\text { Gross } \\
\text { Total }\end{array}$ & CI \\
\hline 1JJ & 166 & 15 & 26.819 & 151 & 2 & 5 & 3 & 4 & 11 & 17.25 & 10.392 \\
\hline 2JJ & 82 & 4 & 14.880 & 78 & 2 & 2 & 0 & 0 & 0 & 1 & 1.220 \\
\hline 3JJ & 148 & 6 & 11.578 & 142 & 3 & 1 & 1 & 0 & 1 & 2.5 & 1.689 \\
\hline $4 \mathrm{JJ}$ & 169 & 0 & 0.000 & 169 & 0 & 0 & 0 & 0 & 0 & 0 & 0.000 \\
\hline $5 \mathrm{JJ}$ & 135 & 0 & 0.000 & 135 & 0 & 0 & 0 & 0 & 0 & 0 & 0.000 \\
\hline $6 \mathrm{JJ}$ & 210 & 18 & 25.768 & 192 & 1 & 4 & 4 & 5 & 4 & 11 & 5.238 \\
\hline $7 \mathrm{JJ}$ & 137 & 10 & 21.347 & 127 & 0 & 1 & 5 & 3 & 1 & 6 & 4.380 \\
\hline $\operatorname{Tr}-1$ & 178 & 14 & 23.865 & 164 & 8 & 1 & 3 & 2 & 0 & 5.25 & 2.949 \\
\hline $\operatorname{Tr}-2$ & 165 & 26 & 47.152 & 139 & 1 & 2 & 9 & 10 & 4 & 16.75 & 10.152 \\
\hline $\operatorname{Tr}-3$ & 82 & 7 & 25.478 & 75 & 0 & 5 & 2 & 0 & 0 & 2.25 & 2.744 \\
\hline $\operatorname{Tr}-4$ & 171 & 26 & 0.000 & 145 & 5 & 2 & 4 & 5 & 10 & 17.5 & 10.234 \\
\hline Tr-5 & 170 & 7 & 12.352 & 163 & 0 & 2 & 5 & 0 & 0 & 3 & 1.765 \\
\hline $\operatorname{Tr}-6$ & 198 & 29 & 44.118 & 169 & 0 & 6 & 4 & 6 & 13 & 21 & 10.606 \\
\hline $\operatorname{Tr}-7$ & 177 & 6 & 9.996 & 171 & 6 & 0 & 0 & 0 & 0 & 1.5 & 0.847 \\
\hline GEN 81 & 195 & 31 & 0.000 & 164 & 0 & 5 & 7 & 5 & 14 & 22.5 & 11.538 \\
\hline $\mathrm{CS} / \mathrm{Bs} / \mathrm{P}$ & 117 & 1 & 2.500 & 116 & 0 & 1 & 4 & 0 & 0 & 2.25 & 1.923 \\
\hline $\mathrm{CS} / \mathrm{Bs} / \mathrm{G}$ & 86 & 3 & 9.838 & 83 & 3 & 5 & 0 & 0 & 0 & 2 & 2.326 \\
\hline $3 \mathrm{JJ} 42$ & 183 & 8 & 13.192 & 175 & 0 & 4 & 5 & 0 & 0 & 3.5 & 1.913 \\
\hline 3JJ44 & 166 & 7 & 12.370 & 159 & 0 & 3 & 4 & 0 & 0 & 2.75 & 1.657 \\
\hline CS & 126 & 27 & 64.264 & 99 & 1 & 3 & 8 & 7 & 8 & 18.25 & 14.484 \\
\hline Amphiploid & 85 & 0 & 0.000 & 85 & 0 & 0 & 0 & 0 & 0 & 0 & 0.000 \\
\hline
\end{tabular}


Table 6. Resistance /susceptibility category of wheat-Thinopyrum bessarabicum genetic stock.

\begin{tabular}{cc}
\hline CI Value/ Category & Genetic stock \\
\hline $0(\mathrm{HR})$ & $4 \mathrm{JJ}, 5 \mathrm{JJ}$, amphiploid \\
$0.1-5(\mathrm{R})$ & $2 \mathrm{JJ}, 3 \mathrm{JJ}, 7 \mathrm{JJ}, \mathrm{Tr}-1 . \mathrm{Tr}-3, \mathrm{Tr}-5, \mathrm{Tr}-7, \mathrm{Tr}-42, \mathrm{Tr}-44$, BC1s self-fertile lines \\
$5.1-10(\mathrm{MS})$ & $6 \mathrm{JJ}$ \\
$10.1-20(\mathrm{~S})$ & $1 \mathrm{JJ}, \mathrm{Tr}-2, \mathrm{Tr}-4, \mathrm{Tr}-6$, Genaro \\
$>20.1(\mathrm{HS})$ & Morocco (Check cultivar) \\
\hline
\end{tabular}

Emebiri et al., 2019). This defense mechanism possesses phenotypic barriers (wax, cell wall, stomatal aperture or lenticles) and chemicals comprise of a diverse array of secondary metabolites (phenolics, sulphur compounds, saponins, cyanogenic glycosides, and glucosinolates) have been synthesized by plant, many of which are deterrent to fungal activity (Osbourn, 1996). Resistance due to secondary metabolite has also been observed in Rice blast disease against different strains of Magnaporthe oryzae (Singh et al., 2020). Broad-spectrum resistance has also been observed due to resistance (R) and defenseregulator(DR) genes to the blast disease of rice (Li et al., 2019). In the light of these studies, it can be demonstrated that amphiploid and addition lines 4J and 5JJ might possess genes encode various plant defense mechanisms including some of above-mentioned physical barriers and or chemical barriers scattered on $4 \mathrm{~J}$ and $5 \mathrm{~J}$ homoeologous chromosomes from Thinopyrum bessarabicum which confer immunity against $\mathrm{KB}$. This result is in accordance with the finding that QTLs for KB resistance are present on 5D (Begum and Mathur, 1989) and on 4B (SukhwinderSingh et al., 2003; Emebiri et al., 2019) chromosomes of wheat. Resistance against KB has also been found in the screening of wheat and rye addition lines on $4 R, 5 R$ and long arm of 7R chromosomes (Sidhu et al., 2001). Other addition line 2JJ, 3JJ, 7JJ, translocation line Tr-1 (6BS.6BL$6 J), \operatorname{Tr}-3$ (3JS.3BL), Tr-5 (7DS.7DL-4J), Tr-7 (5JS-5DS.5DL), $\operatorname{Tr}-42(2 \mathrm{n}=6 \mathrm{X}=41+\operatorname{Tr} 3 \mathrm{~J}), \operatorname{Tr}-44(2 \mathrm{n}=6 \mathrm{X}=42+\operatorname{Tr} 3 \mathrm{JJ})$, and two $\mathrm{BC} 1 \mathrm{~s}$ self-fertile lines $((2 \mathrm{n}=7 \mathrm{X}=42+7 \mathrm{~J})$ also possess resistance gene(s) distributed on different homoeologous Th. bessarabicum chromosomes/ chromosomal arms, as QTLs for KB resistance are also present on 2A, 3B, 3D, 5D, 7A (Begum and Mathur, 1989; Emebiri et al., 2019) and 4B chromosomes of wheat (Sukhwinder-Singh et al., 2003). Homoeology of Thinopyrum bessarabicum chromosomes with wheat have already been explained in another study carried out by William and Mujeeb-Kazi (1995). These highly resistant addition and translocation lines of wheatTh. bessarabicum identified in the present screening stands as a preferred candidate for $\mathrm{KB}$ resistance as an added positive attribute from tertiary gene pool.

\section{References}

AKFIRAT, S.F., AYDIN, Y., ERTUGRUL, F., HASANCEBI, S., BUDAK, H., AKAN, K., MERT, Z., BOLAT, N. and UNCUOGLU, A., 2010. A microsatelite marker for yellow rust resistance in wheat cereal. Research Communication, vol. 38, pp. 203-210.
ALI, S., RODRIGUEZ-ALGABA, J., THACH, T., SØRENSEN, C.K., HANSEN, J.G., LASSEN, P., NAZARI, K., HODSON, D.P., JUSTESEN, A.F. and HOVMØLLER, M.S., 2017. Yellow rust epidemics worldwide were caused by pathogen races from divergent genetic lineages. Frontiers in Plant Science, vol. 8, pp. 1057. http://dx.doi. org/10.3389/fpls.2017.01057. PMid:28676811.

AUJLA, S.S., SHARMA, I. and SINGH, B.B., 1989. Rating scale for identifying wheat varieties resistant to Neovossia indica. Indian Phytopathology, vol. 42, pp. 161-162.

BEGUM, S. and MATHUR, S.B., 1989. Genetics of resistance to Karnal bunt and loose smut in wheat. FAO Plant Protection Bulletin, vol. 37, no. 4, pp. 165-173.<jrn>

BENIWAL, M. S., PANKAJ-CHAWLA and RAJENDER-SINGH, 2001. Comparison of different methods of inoculationand evaluation of wheat material against Neovossia indica (Mitra) Mundkur. Crop Research Hisar, vol. 21, pp. 105-108.

BISHNOI, S.K., HE, X., PHUKE, R.M., KASHYAP, P.L., ALAKONYA, A., CHHOKAR, V., SINGH, R.P. and SINGH, P.K., 2020. Karnal Bunt: a Re-emerging old foe of wheat. Frontiers in Plant Science, vol. 11, pp. 569057. http://dx.doi.org/10.3389/fpls.2020.569057. PMid:33133115.

BONDE, M.R., PETERSON, G.L., SCHAAD, N.W. and SMILANICK, J.L., 1997. Karnal bunt of wheat. Plant Disease, vol. 81, no. 12, pp. 1370-1377. http://dx.doi.org/10.1094/PDIS.1997.81.12.1370. PMid:30861787.

BRAR, G.S., FUENTES-DÁVILA, G., HE, X., SANSALONI, C.P., SINGH, R.P. and SINGH, P.K., 2018. Genetic mapping of resistance in hexaploid wheat for a quarantine disease: karnal Bunt. Frontiers of Plant Science, vol. 9, pp. 1497. http://dx.doi.org/10.3389/ fpls.2018.01497. PMid:30386358.

CARRIS, L.M., CASTLEBURY, L.A. and GOATES, B.J., 2006. Nonsystemic Bunt Fungi- Tilletia indica and T. horrida: a review of history, systematics, and biology. Annual Review of Phytopathology, vol. 44, no. 1, pp. 113-133. http://dx.doi.org/10.1146/annurev. phyto.44.070505.143402. PMid:16480336.

CHAKRAVARTY, B., 2011. Trends in Mushroom cultivation and breeding. Australian Journal of Agricultural Engineering, vol. 2, pp. 102-109.

CHEN, X.M., 2005. Epidemiology and control of stripe rust [Puccinia striiformis f. sp. tritici] on wheat. Canadian Journal of Plant Pathology, vol. 27, no. 3, pp. 314-337. http://dx.doi. org/10.1080/07060660509507230.

CHEN, X.M., 2013. Review Article: high-temperature adult-plant resistance, key for sustainable control of stripe rust. American Journal of Plant Sciences, vol. 4, no. 03, pp. 608-627. http://dx.doi. org/10.4236/ajps.2013.43080.

EMEBIRI, L., SINGH, S., TAN, M.K., SINGH, P.K., FUENTES-DÁVILA, G. and OGBONNAYA, F., 2019. Unravelling the complex genetics of Karnal Bunt (Tilletia indica) resistance in common wheat (Triticum aestivum) by genetic linkage and genome-wide 
association analyses. G3 (Bethesda, Md.), vol. 9, no. 5, pp. 14371447. http://dx.doi.org/10.1534/g3.119.400103. PMid:30824480.

FARROKHI, J., DARVISHZADEH, R., NASERI, L., MOHSENI AZAR, M. and HATAMI MALEKI, H., 2011. Evaluation of genetic diversity among Iranian apple (Malus domestica Borkh.) cultivars and landraces using simple sequence repeat markers. Australian Journal of Crop Science, vol. 5, pp. 815-821.

FEUILLET, C., LANGRIDGE, P. and WAUGH, R., 2008. Cereal breeding takes a walk on the wild side. Trends in Genetics, vol. 24, no. 1, pp. 24-32. http://dx.doi.org/10.1016/j.tig.2007.11.001. PMid:18054117.

FOOD AND AGRICULTURE ORGANIZATION - FAO. INTERNATIONAL FUND FOR AGRICULTURAL DEVELOPMENT - IFAD. UNITED NATIONS INTERNATIONAL CHILDREN'S EMERGENCY FUND - UNICEF. WORLD FOOD PROGRAMME - WFP, and WORLD HEALTH ORGANIZATION - WHO, 2018. 2018 -The state of food security and nutrition in the world 2018: building climate resilience for food security and nutrition. Geneva: FAO, pp. 202.

FOSTER, A.J., LOLLATO, R., VANDEVEER, M. and DE WOLF, E.D., 2017. Value of fungicide application in wheat production in Southwest Kansas. Kansas Agricultural Experiment Station Research Reports, vol. 3, no. 5, pp. 8. http://dx.doi.org/10.4148/2378-5977.7385.

GARRETT, K.A. and BOWDEN, R.L., 2002. An Allee effect reduces the invasive potential of Tilletia indica. Phytopathology, vol. 92, no. 11, pp. 1152-1159. http://dx.doi.org/10.1094/PHYTO.2002.92.11.1152. PMid:18944239.

GETACHEW, G.M. and BIRUK, K.M., 2018. Assessment on spatial distribution and their management options against wheat rust (Puccinia spp.) disease species in selected administrative zones of southern Ethiopia. International Journal of Research in Agriculture and Forestry, vol. 5, no. 3, pp. 8-16.

GILL, K.S., NANDA, G.S., SINGH, G., CHAND, K., AUJLA, S.S. and SHARMA, I., 1993. Study of gene effects for Karnal Bunt (Neovossia indica) resistance in bread wheat (Triticum aestivum L). Indian Journal of Genetics, vol. 50, pp. 205-209.

GOGOI, R., SINGH, D.V., SRIVASTAVA, K.N., TOMAR, S.M.S. and SRIVASTAVA, K.D., 2002. Morphological and isozymic variations among karnal bunt resistant and susceptible genotypes of wheat - a comparison\}. Acta Phytopathologica et Entomologica Hungarica, vol. 37, no. 1-3, pp.99-108. http://dx.doi.org/10.1556/ APhyt.37.2002.1-3.11.

GUPTA, V., HE, X., KUMAR, N., FUENTES-DÁVILA, G., SHARMA, R.K., DREISIGACKER, S., JULIANA, P., ATAEI, N. and SINGH, P.K., 2019. Genome wide association study of Karnal bunt resistance in a wheat germplasm collection from Afghanistan. International Journal of Molecular Sciences, vol. 20, no. 13, pp. 3124. http:// dx.doi.org/10.3390/ijms20133124. PMid:31247965.

GURJAR, M.S., AGGARWAL, R., JOGAWAT, A., KULSHRESHTHA, D., SHARMA, S., SOLANKE, A.U., DUBEY, H. and JAIN, R.K., 2019. De novo genome sequencing and secretome analysis of Tilletia indica inciting Karnal bunt of wheat provides pathogenesis related genes. Biotechnology (Faisalabad), vol. 9, no. 6, pp. 219 http://dx.doi.org/10.1007/s13205-019-1743-3. PMid:31114743.

HOVMøLLER, M.S., RODRIGUEZ-ALGABA, J., THACH, T. and SØRENSEN, C., 2017. Race typing of Puccinia striiformis on wheat. In: S. PERIYANNAN, eds. Methods in molecular biology. New York, NY: Humana Press.

JINYA, S., DEWEI, Y., BAUFENG, S., MI, Z., CUNJIA, L., XIAOPING, H., XIANGMING, X., LEI, G. and WEN, H.C., 2020. Aerial visual perception in smart farming: field study of wheat yellow rust monitoring. IEEE Transactions on Industrial Informatics, vol. 17, no. 3, pp. 2242-2249. http://dx.doi.org/10.1109/TII.2020.2979237.
KASHYAP, P.L., KAUR, S. and PANNU, P.P.S., 2018. Induction of systemic tolerance to Tilletia indica in wheat by plant defence activators. Archiv für Phytopathologie und Pflanzenschutz, vol. 51, no. 1-2, pp. 1-13. http://dx.doi.org/10.1080/03235408.2018.1438778.

KERBER, E.R. and DYCK, P.L., 1990. Transfer to hexaploid wheat of linked genes for adult-plant leaf rust and seedlings rust resistance from an amphiploid of Aegilops speltoides x Triticum monococcum. Genome, vol. 33, no. 4, pp. 530-537. http://dx.doi. org/10.1139/g90-079.

KLARQUIST, E.F., CHEN, X.M. and CARTER, A.H., 2016. Novel QTL for stripe rust resistance on chromosomes $4 \mathrm{~A}$ and $6 \mathrm{~B}$ in Soft white winter wheat cultivars. Agronomy (Basel), vol. 6, no. 1, pp. 1-14. http://dx.doi.org/10.3390/agronomy6010004.

KUMAR, S., SINGH, D. and PANDEY, V.K., 2014. Field screening of wheat genotypes against Karnal bunt caused by Neovossia indica (Mitra) Mund. Electronic Journal of Plant Breeding, vol. 5, pp. 602-604.

KUMAR, S., SINGROHA, G., BHARDWAJ, S.C., BALA, R., SAHARAN, M.S., GUPTA, V., KHAN, A., MAHAPATRA, S., SIVASAMY, M., RANA, V., MISHRA, C.N., PRAKASH, O., VERMA, A., SHARMA, P., SHARMA, I., CHATRATH, R. and SINGH, G.P., 2019. Multienvironmental evaluation of wheat (Triticum aestivum L.) germplasm identifies donors with multiple fungal disease resistance. Genetic Resources and Crop Evolution, vol. 66, no. 4, pp. 797-808. http://dx.doi.org/10.1007/s10722-019-00751-3.

LI, W., CHERN, M., YIN, J., WANG, J. and CHEN, X., 2019. Recent advances in broad-spectrum resistance to therice blast disease. Current Opinion in Plant Biology, vol. 50, pp. 114-120. http:// dx.doi.org/10.1016/j.pbi.2019.03.015. PMid:31163394.

LINE, R.F. and QAYOUM, A., 1992. Virulence, aggressiveness, evolution, and distribution of races of Puccinia striiformis (the cause of stripe rust of wheat) in North America, 1968-87. USA: US Department of Agriculture, Agriculture Research Services. Technical Bulliten, no. 1788.

LINE, R.F., 2002. Stripe rust of wheat and barley in North America: a retrospective historical review. Annual Review of Phytopathology, vol. 40, no. 1, pp. 75-118. http://dx.doi.org/10.1146/annurev. phyto.40.020102.111645. PMid:12147755.

MARCELO, C., SAUTUA, F., PÉREZ-HÉRNANDEZ, O. and REIS, E.M., 2020. Role of fungicide applications on the integrated management of wheat stripe rust. Frontiers in Plant Science, vol. 11, pp. 733. http://dx.doi.org/10.3389/fpls.2020.00733. PMid:32582257.

MCINTOSH, R., MU, J., HAN, D. and KANG, Z., 2018. Wheat stripe rust resistance geneYr24/Yr26: Aretrospective review. The Crop Journal, vol. 6, no. 4, pp. 321-329. http://dx.doi.org/10.1016/j. cj.2018.02.001.

MCINTOSH, R.A., WELLINGS, C.R. and PARK, R.F., 1995. Wheat rusts: an atlas of resistance genes. Dordrecht: Kluwer Academic Publishers.

MENGESHA, G. G., 2020. Management of yellow rust (Puccinia striiformis f.sp. tritici) and stem rust (Puccinia graminis f.sp tritici) of bread wheat through host resistance and fungicide application in Southern Ethiopia. Cogent Food and Agriculture, vol. 6, no. 1, 1739493. http://dx.doi.org/10.1080/23311932.20 20.1739493 .

MILUS, E.A., LEE, K.D. and BROWN-GUEDIRA, G., 2015. Characterization of stripe rust resistance in wheat lines with resistance gene $\mathrm{Yr} 17$ and implication for evaluating resistance and virulence. Phytopathology, vol. 105, no. 8, pp. 1123-1130. http://dx.doi.org/10.1094/PHYTO-11-14-0304-R. PMid:25775101.

MITRA, M., 1931. A new bunt on wheat in India. Annals of Applied Biology, vol. 18, no. 2, pp. 178-179. http://dx.doi. org/10.1111/j.1744-7348.1931.tb02294.x. 
NARANG, D., KAUR, S., STEUERNAGEL, B., GHOSH, S., BANSAL, U., LI, J., ZHANG, P., BHARDWAJ, S., UAUY, C., WULFF, B.B.H. and CHHUNEJA, P., 2020. Discovery and characterisation of a new leaf rust resistance gene introgressed in wheat from wild wheat Aegilops peregrina. Scientific Reports, vol. 10, no. 1, pp. 7573. http://dx.doi.org/10.1038/s41598-020-64166-2. PMid:32371881.

OSBOURN, A.E., 1996. Preformed antimicrobial compounds and plant defense against Fungal Attack. The Plant Cell, vol. 8, no. 10, pp. 1821-1831. http://dx.doi.org/10.2307/3870232. PMid:12239364.

PANDEY, V., GUPTA, A.K., SINGH, M., PANDEY, D. and KUMAR, A., 2019. Complementary proteomics, genomics approaches identifies potential pathogenicity/virulence factors in Tilletia indica induced under the influence of host factor. Scientific Reports, vol. 9, no. 1, pp. 553. http://dx.doi.org/10.1038/s41598018-37810-1. PMid:30679765.

RAZA, S., UMAR, U.U.D., MUHAMMAD, F., REHMAN, A.U., NAQVI, S.A.H. and SHERWANI, H.U.K., 2019. Efficient approaches for the management of Karnal bunt of Wheat caused by Nevossia indica. Pakistan Journal of Phytopathology, vol. 31, no. 2, pp. 177-188.

REIF, J.C., ZHANG, P., DREISIGACKER, S., WARBURTON, M.L., VAN GINKEL, M., HOISINGTON, D., BOHN, M. and MELCHINGER, A.E., 2005. Wheat genetic diversity trends during domestication and breeding. Theoretical and Applied Genetics, vol. 110, no. 5, pp. 859-864. http://dx.doi.org/10.1007/s00122-004-1881-8. PMid:15690175.

ROBERT-SEILANIANTZ, A., GRANT, M. and JONES, J.D., 2011. Hormone crosstalk in plant disease and defense: more than just jasmonate-salicylate antagonism. Annual Review of Phytopathology, vol. 49, no. 1, pp. 317-343. http://dx.doi. org/10.1146/annurev-phyto-073009-114447. PMid:21663438.

ROSEWARNE, G.M., HERRERA-FOESSEL, S.A., SINGH, R.P., HUERTAESPINO, J., LAN, C.X. and HE, Z.H., 2013. Quantitative trait loci of stripe rust resistance in wheat. Theoretical and Applied Genetics, vol. 126, no. 10, pp. 2427-2449. http://dx.doi.org/10.1007/ s00122-013-2159-9. PMid:23955314.

RUSH, C.M., STEIN, J.M., BOWDEN, R.L., RIEMENSCHNEIDER, R., BORATYNSKI, T. and ROYER, M.H., 2005. Status of Karnal bunt of wheat in the United States 1996-2004. Plant Disease, vol. 89, no. 3, pp. 212-223. http://dx.doi.org/10.1094/PD-89-0212. PMid:30795341.

SAJJAD, M., AHMAD, S., HUSSAIN, M.A., GHAZALI, H.M.Z.U., NASIR, M., FAYYAZ, M., and HUSSAIN, M., 2018. Incidence of Karnal bunt (Tilletia indica Mitra) of wheat in southern Punjab, Pakistan. International Journal of Biosciences, vol. 12, no. 2, pp. 280-285. http://dx.doi.org/10.12692/ijb/12.2.280-285.

SHAKOOR, M.A., AHMAD, M., SHAHID, M.R. and HUSSAIN, M., 2015. Screening of advanced lines and commercial varieties of wheat against karnal bunt disease. International. Journal of Advance Research and Biological Science., vol. 2, no. 5, pp. 17-22.
SIDHU, M. C., SATIJA, C. K., SHARMA and INDU, 2001. Screening of wheat-rye addition lines for karnal bunt resistance. Crop Improvement, vol. 28, no. 2, pp. 214-217.

SINGH, R.P., WILLIAM, H.M., HUERTA-ESPINO, J. and ROSEWARNE, G., 2004. Wheat Rust in Asia: Meeting the challenges with old and new technologies. In: New directions for a diverse planet: Proceedings of the 4th International Crop Science Congress. Brisbane, Australia.

SINGH, J., GUPTA, S.K., DEVANNA, B.N., SINGH, S., UPADHYAY, A. and SHARMA, T.R., 2020. Blast resistance gene pi54 over-expressed in rice to understand its cellular and sub-cellular localization and response to different pathogens. Science Report, vol. 10, pp. 5243. http://dx.doi.org/10.1038/S41598-020-59027-X.

SINGH, S., GILL, K.S., DHALIWAL, H.S., SINGH, H. and GILL, B.S., 1994. Towards molecular tagging of Karnal bunt resistance gene(s) in wheat. Journal of Plant Biochemistry and Biotechnology, vol. 3, no. 2, pp. 79-83. http://dx.doi.org/10.1007/BF03321955.

SINGH, S., SHARMA, I., SEHGAL, S. K., BAINS, N.S., GUO, Z., NELSON, J. C. and BOWDEN, R.L., 2007. Molecular mapping of QTLS for Karnal bunt resistance in two 137 recombinant inbred populations of bread wheat. Theoretical Applied Genetics, vol. 116, pp. 147-154. http://dx.doi.org/10.1007/s00122-007-0654-6.

SUKHWINDER-SINGH, BROWN-GUEDIRA, G.L., GREWAL, T.S., DHALIWAL, H.S., NELSON, J.C., SINGH, H. and GILL, B.S., 2003. Mapping of a resistance gene effective against Karnal bunt pathogen of wheat. Theoretical and Applied Genetics, vol. 106, no. 2, pp. 287-292. http://dx.doi.org/10.1007/s00122-0021112-0. PMid:12596729.

SUKHWINDER, S., SHARMA, I., SEHGAL, S.K., BAINS, N.S., GUO, Z., NELSON, J.C. and BOWDEN, R.L., 2007. Molecular mapping of QTLs for Karnal bunt resistance in two 137 recombinant inbred populations of bread wheat. Theoretical and Applied Genetics, vol. 116, pp, 147-154. http://dx.doi.org/10.1007/s00122-0070654-6.<jrn>

WARHAM, E. J., 1988. Screening for Kamal bunt (Tilletia indica) resistance in wheat, triticale, rye and barley. Canadian Journal of Plant Pathology, vol. 10, pp. 57-60.

WILLIAM, M.D. and MUJEEB-KAZI, A., 1995. Biochemical and molecular diagnostics of Thinopyrum bessarabicum chromosomes in Triticurn aestivum germ plasm. Theoretical and Applied Genetics, vol. 90, no. 7-8, pp. 952-956. http://dx.doi. org/10.1007/BF00222908. PMid:24173049.

WULFF, B.B.H. and MOSCOU, M.J., 2014. Strategies for transferring resistance into wheat: from wide crosses to GM cassettes. Frontiers of Plant Science, vol. 5, pp. 692. http://dx.doi. org/10.3389/fpls.2014.00692. eCollection 2014.

ZADOKS, J.C., CHANG, T.T. and KONZAK, C.F., 1974. A decimal code for growth stages of cereals. Weed Research, vol. 14, pp. 415-421. 